\title{
Union responses to precarious workers: Italy and Spain compared
}

\author{
Valeria Pulignano (KU Leuven), Luis Ortiz (Pompeu Fabra University) Fabio de Franceschi \\ (KU Leuven)
}

This article will be published in the European Journal of Industrial Relations.

\begin{abstract}
Transformations of European labour markets and welfare systems have deepened the problem of precarious work. This has led trade unions to develop strategies to represent and organise precarious workers. By focusing on Italy and Spain, two of the countries with the highest incidence of precarious jobs in Europe, the paper addresses the specificity and variety of union responses towards precarious work. It refers these responses to the different institutional contexts, including employment and social welfare regulatory settings, and the power resources union can draw upon.
\end{abstract}

Keywords: precarious work, atypical work, trade unions, comparative industrial relations, welfare, labour market, power resources.

\section{Introduction}

Precarious work is characterised by a combination of atypical employment contracts, limited or no social benefits and statutory entitlements, high degrees of job insecurity or short tenure, low wages and/or high risks of occupational injury and disease (Evans and Gibb, 2009). Some literature has emphasised rational choice theory as well as political motivations and ideology in order to explain unions' strategies for representing precarious workers' interests (Bacon and Blyton, 2004). Labour markets and welfare regimes, which differ markedly across Europe, may also contribute to explaining cross-national differences in the unions' approach towards precarious work (Lodemel and Trickey, 2001).

Labour markets in Italy and Spain are among those with the highest incidence of precarious jobs in Europe. The paper investigates the variety and specificity of union practices and strategies to represent precarious workers' interests, paying special attention to the institutional context and the power resources unions can draw upon.

The analysis is based on 34 semi-structured interviews: 15 in Italy and 19 in Spain. Interviews were undertaken during 2011-2012 (with follow-up in October 2014) with union officers belonging to atypical unions' federations, officers in the self-employed and youth associations affiliated to unions in Italy and Spain, particularly in Catalonia one of the largest industrial regions of Spain, and one of the main strongholds of Spanish unionism - and therefore singled out as the paradigm of practices to be later found in other regions of Spain (Fishman, 2004). Documentary data, in the forms of reports, collective agreements, leaflets and websites of the different national unions federations and the federations for the atypical work (where existent), complemented the semi-structured interviews.

After analysing union strategies towards precarious work in Europe, we will present the nature and the causes of precarious work in Italy and Spain. Then, the responses to precarious work by different unions are presented and analysed.

\section{Union responses to precarious work in Europe}

Strategies towards precarious work have recently become a dilemma for trade unions. On the one hand, unions can reject atypical work on the grounds that jobs should be stable, establish a clear relationship between employers and employees, and guarantee a sufficient wage for the subsistence of workers and their families. On the other hand, unions can assume the existence of 
atypical work and adopt strategies aimed at improving the working conditions, social rights and wages linked to them.

The way unions deal with atypical workers and their specific interests is directly influenced by their general attitude towards atypical work. Heery (2009) illustrates different strategies that unions can adopt to represent atypical workers: the 'exclusion' of atypical workers; the 'subordination' of their interests to the ones of 'standard' workers; the 'inclusion', and the active 'engagement' in defending their interests., Trade union power resources - as structural, associational, organisational, institutional, discursive and strategic - are considered as equally important as the unions' general attitude towards atypical work in order to understand how they respond to the challenges of precarious work (Gumbrell-McCormick and Hyman, 2013).

Furthermore, considerations about the strategies towards precarious workers are linked to the debate about whether unions should abandon the 'servicing model' based on the provision of 'union representation' services (such as collective bargaining) and embrace an 'organising' (or 'mobilising') model, where members are actively engaged by workplace activists and take responsibility in union activities (Fiorito and Jarley, 2009). Given that there is little evidence of attitudinal differences towards union affiliation between typical and atypical workers (Kretsos, 2011), the lower union density among the latter is explained mainly by structural factors within labour markets, such as their weaker link to a single workplace and their higher tendency to be employed in sectors (e.g. service) where union presence is weaker (Carre' et al., 2000).

However, analyses based on a variety of institutional contexts bring different recommendations. Studies in the UK, for example, play down the effectiveness of collective bargaining because of the lack of a clear counterpart (Heery, 2009). Kretsos' analysis of unions' strategies towards precarious work in Greece advocates the use of stronger organising strategies to affiliate and mobilise atypical workers at the workplace (2011). A similar point is defended by Vandaele and Leschke (2010) who conclude that the adoption of a simple organising model is not sufficient to successfully represent the interests of precarious workers, hence somewhat agree that a well-designed mix of the two strategic approaches should be implemented.

Some studies, but not many, have also raised the question of unions creating or adapting their organisational structures to address precarious work. Gumbrell-McCombrick (2010), for example, found out that only in Italy, and more limitedly in the Netherlands, unions form specific structures to represent atypical workers, while in other European countries unions just use the organisations in place for this aim.

The variation in union strategies towards precarious work points to the complex interaction between union strategies and structures. The latter is strongly influenced by the institutional environment in which unions are embedded and from which they pull their resources (Boxall, 2009). By drawing from this literature we contextualise the responses of Spanish and Italian unions towards precarious work in their institutional context, and consider the resources unions can use to protect precarious employment. It includes the consideration of the main features concurring to characterise what 'precarious job' means in each national context.

\section{Case selection}

Italy and Spain have the highest incidence of precarious work and in-work-at-risk-of poverty in Europe (Keune, 2013: 6). In particular, in Italy the in-work-at-risk-of-poverty rate increased from $8.8 \%$ in 2005 to $9.4 \%$ in 2010, and in Spain it reached 12,7\% in 2010 (from 10.4 in 2005).

Both countries also show non-negligible differences and similarities. Regarding the differences, while self-employment is the dominant form of nonstandard work in Italy, in Spain temporary employment is more common (Hipp, et al. 2015). Specifically, although fixed-term employment has declined in Spain during the recession, it has always been exceptionally high in European terms, and substantially higher than in Italy, where the percentage of fixed-term contracts in 2001 was close to the EU average. Eurostat (2013) illustrate that the incidence of 
youth employees between 15-29 who hold a temporary contract became higher $(49,3 \%)$ in Spain than in Italy $(39,6 \%)$ in 2013. Moreover, even though union power in both countries depends more on the result of works council's election than on the number of members, the result of union elections is not as important in relative terms in Italy as in Spain. In Italy union bargaining power at the workplace is traditionally strictly related to the capacity of the union to recruit and mobilise members (Terry, 1993). It reflects the logics of organisation and movement of Italian trade unionism, which is at the basis of the union capacity to adapt to a more inclusive range of actions, whereby representation is not simply understood as only protection of union members in the strictest sense (Regalia, 2012). Spanish unions, on the contrary, remain in their action largely independent of union membership levels, which are comparatively lower than in Italy.

Yet, the two countries have somehow converged. During the period 2005-2013 the incidence of youth unemployed has increased in Italy (almost 10\%), while it has remained relatively stable in Spain. Similarly, although EPL (employment protection legislation) has been reduced for both temporary and permanent employment in both countries since the mid-1990s, the decrease has been steeper in Italy than in Spain, also resulting in a sort of convergence between the two countries' employment insecurity (see Table 1).

[Table 1 about here]

\section{Labour markets development and characteristics of precariousness}

\section{Italy}

Since 1980s the Italian labour market has gone through a process of flexibilisation, characterised by the implementation of work-and-training-contracts, followed by a weakening of the strict rules for fixed-term contracts (L.56/1987). Hereby new forms of self-employment, sub-contracting and bogus self-employment became more accessible for firms willing to compete on labour costs. However, the big step was made in 1997 by the centre-left government (Treu Law 196/1997), which aimed to increase the employment rate by introducing agency work, liberalising the job placement market, and extending other forms of atypical work. Berlusconi's centre-right government in 2001 pushed further along this path. The government published a 'White Book', which was followed by the 2002 'Pact for Italy' signed by Confindustria, the main employers' organisation, and two of the three main union confederations, CISL and UIL. Then the "Legge Biagi" (Law 30/2003) was introduced taking many of the aspects included in the 2002 Pact. This law introduced several forms of atypical contracts explicitly aimed at increasing employment by widening employers' choice.

Labour market protection in Italy is not higher than in many other European countries (Carrieri and Burroni, 2013) but since the beginning of the 1990s the protection of temporary employment radically declined, probably as a consequence of the several reforms which increased labour market fragmentation. After the Law 30/2003, for example, there have been more than 40 different types of employment relationships counted (Ballarino, 2005), of which only one (access-to-work-contract or contratto di inserimento) has been abolished by the 2012 Fornero reform (Rymkevich, 2013).

Labour market deregulation went in parallel with the creation of less protected jobs, fostering labour market segmentation, more markedly in the 2000s (OECD, 2002). Overall, the result has been the creation of a form of precariousness tied to short job tenure, absent or very limited social protection, and the lack of basic standard workers' rights (sick-leave, maternity leave, vacation etc.) (Barbieri, 2011).

Although Italy is more or less in line with the EU average as regards the use of parttime and fixed-term work, it is remarkably above the EU average in the use of dependent and independent self-employment as well as informal and undeclared jobs (Altieri, 2009). Moreover, Italy has been one of the few EU countries where temporary contracts have been used quite regularly and mostly in a not voluntary way (Burroni and Carrieri, 2013). 
Leonardi (2009) reports that self-employed workers represent $17 \%$ of the national employment rate; and most of them are composed of so-called 'coordinated and continuous assistants', a sort of a semi-subordinated worker, legally autonomous but economically dependent. Together with the 'undeclared employees', self-employed represent a peculiarity of the Italian way to flexibility and precariousness since unlike all the other atypical work they fall outside labour law protections. They include freelance coordinated workers, occasional freelance coordinate workers, occasional autonomous workers and project workers.

Although temporary agency workers have the same rights (particularly pay treatment) as employees of the user-firm, they have also weaker income security for the periods of unemployment. This is one of the biggest problems faced by Italian atypical workers in general. Since the mid-2000s, several reforms were introduced to strengthen the duration and quantity of unemployment benefits (Decree Law 185/08 and Laws 2/09 and 191/09). Trade unions were actively engaged in their negotiation. However, the social security system remained largely unchanged; that is, still tailored to the needs and characteristics of standard workers, which since 1990s have kept a quite stable level of social protection, with the exception of 2012, when EPL for regular workers was slightly reduced by the 2012 Fornero reform.

The shortage of a fair and inclusive system of social protection in case of unemployment increases the sense of precariousness felt by Italian atypical workers (Accornero, 2006). Some observers add the low level of salaries and active labour market policy. Temporary workers in Italy are more likely to receive lower wages than workers with standard contracts independently of the level of qualification or seniority (IRES, 2010). In addition, the level of expenditure on labour market policies, measured as a percentage of GDP, is lower in Italy than in many European countries (including Spain). Although efforts have been made to attribute social security guarantees to atypical employment, non-standard employment is still disadvantaged in comparison with standard employment. This is particularly true regarding social security and 'shock absorbers'. According to Berton et al (2009), for example, around $90 \%$ of standard employment has the possibility of receiving unemployment benefits, while the percentage declines to $40 \%$ for temporary contracts and to $30 \%$ for agency workers. Similarly, welfare rights, particularly pension, maternity and sick pay, are those the country considers 'very essential' but also 'weakly attainable' (Kay et al. 2012). This may explain the pressing need for Italian trade unions to defend atypical workers by negotiating different reforms from the beginning of the 1990s (Laws 223/91; 236/93; 451/94 and the Anti-crisis Decree - Law $2 / 2009$ ), aiming at increasing the quantity of funds for social shock absorbers and enlarged their applicability to workers previously excluded (i.e. fixed-term workers, apprentices, and agency workers).

In sum, precarious employment in Italy was generated by the causal relation between the process of rapid (and uncontrolled) flexibilization and deregulation since 1997 and the shortcomings of the social security and welfare system, which guarantees constrained entitlements to workers engaged in 'flexible jobs'. The duration of the employment contract associated with the workers' entitlement to social rights is the distinctive features of precarious work.

\section{Spain}

The current democratic regime in Spain was born in a period of economic crisis, mostly due to the 1970s oil crises and the low competitiveness of Spanish companies in international markets at the time when the Spanish economy aspired to join the European Common Market. Confronted with unemployment as a major economic and political challenge for the newly arrived democracy, employment creation became a top priority for the Spanish Socialist Party (PSOE) when it won the 1982 general elections. The PSOE government envisaged labour market deregulation as the primary way of achieving the goal of employment creation. Employers' interests focused on reducing dismissal costs, regarded by them as an obstacle for employment creation. The two main trade union confederations (UGT and CCOO) were instead 
interested in preserving the rights they had fought for during the end of Francoist dictatorship at the beginning of the democratic period.

In such a scenario it was not by chance that the brunt of the bargaining process between government, employers and unions was to be borne by those who were still to enter into the labour market (Fernández Macías, 2003). In 1984, the first reform of the Spanish labour market was agreed by PSOE, the employers' association (CEOE) and the socialist trade union confederation (UGT), although it was rejected by the other trade union confederation (CCOO). The reform allowed an almost indiscriminate use of a new type of temporary contract ('employment-promotion fixed-term contract') by employers, leaving severance payments of permanent contracts almost untouched. Temporary employment subsequently grew at a steep pace, leading to a reform in 1994, which virtually eliminated the 'employment-promotion fixedterm contracts'.

The reforms of the Spanish labour market in the 1980s and 1990s brought about a dramatic process of labour market segmentation. Labour market entrants during the next upward economic cycle were mostly hired with temporary contracts, which covered $73 \%$ of the new contracts in 1985-1993 (Conde-Ruiz et al., 2010). Neither the 1984 reform nor the subsequent ones eliminated completely the problem of unemployment. And temporary employment demonstrated to be a trap rather than a stepping stone towards permanent employment (Polavieja, 2005).

It was not until 1997 that a new labour market reform explicitly addressed the new problem generated by the growth of temporary employment. In return for gaining some ground lost in the decentralization of collective bargaining in the previous reform, trade unions accepted less stringent rules in dismissal conditions for a new type of permanent contract with lower severance payment (Molina, 2007). The reform also established stricter conditions on the use of temporary employment.

Despite the fact that the 1997 reform aimed at reducing its proportion, the rate of temporary employment was not substantially altered. According to Dolado et al (2002), the resilience of temporary employment is explained by the fact that the decrease in the use of temporary contracts by the private sector, fostered by the 1997 reform, was offset by the increase in the use of temporary employment by the public sector, triggered in part by fiscal consolidation pursued by the Spanish government after the Maastricht Treaty (see Graph 1).

[Graph 1 about here]

\section{Union responses to precariousness: Italy}

In spite of the initial attempts made by the government, employers and trade unions, under the centre-left Prodi government in 2007 to implement some measures to improve unemployment benefit for young people, more entrapped in forms of precarious work, the very poor income during the period they are not working is still one of the problems of Italian precarious workers, along with the extent to which they can access the same rights and labour conditions of regular workers. This raises a central aspect in understanding how the Italian unions have responded to the challenge of precarious work, which is the protection of atypical workers through the creation of specific structures for the representation of those workers. As the president of the Italian trade union federation for atypical workers in NIDIL-CGIL argues:

"After the 1997 Treu-reform Italian unions have strategically chosen to represent workers by creating non-standard dedicated federations inside the confederations (..) this is in line with the Italian tradition of 'confederalismo' (..). The aim is to promote the rights of atypical workers. We wanted to attribute "dignity" to atypical workers while settings up structures able to overcome the growing labour market segmentation based on the persistence of different social provisions between atypical and typical workers" (Brussels, October 2014) 
Italian unions established new organisations aimed at representing flexible and often precarious workers (e.g. workers with temporary contracts, temporary agency workers and dependent self-employed) to regulate these forms of work. Hereby, CGIL created NIDIL (Nuove Identita' del Lavoro), CISL set up an association called Alai (Associazione Lavoratori Atipici e Interinali now with the status of federation as FeLSA), while UIL created CPO-UIL (Comitati per l'Occupazione), from 2010 called UIL Tem.p@.

The process that led to the creation of the Italian union structures representing atypical workers started since mid-1990s when self-associations and self-organised networks were set up by groups of freelancers, such as the association 'Collaboratori e Consulenti Associati' (Ballarino, 2005). For example, the creation of NIDIL-CGIL was not only the strategic decisions by the CGIL; it was also supported by the self-organized precarious workers (Choi and Mattoni, 2010).

The organisational solution offered by the Italian unions to represent atypical workers is innovative, since the common basis of representation has always been the sector, trade or occupation. In this respect, it is quite distinctive in comparison to the traditionally locally-based offices or specialised work groups already created by the unions to improve the organisation and representation of women and immigrants (Cella, 2012). Particularly, the newly established union federation for atypical workers are cross-wise unions, whose explicit objective is to increase the protection afforded to self-employed or semi-autonomous work (Collaborazioni coordinate e continuative, or Co.co.co.) and temporary workers through collective bargaining and shop-floor representation. NIDIL-CGIL, for example, describes itself as a union that gives voice and representation to atypical workers who work without social protection. In this respect, NIDIL claims to pursue two main goals: raising awareness for the issue of precarious work and for the problems and realities of precarious workers; improving working conditions for precarious workers through re-regulation and organizing on multiple levels inside the union federation, in society, and at the workplace (CGIL-NIDIL 2006).

Although the atypical federations represent a small proportion of the total precarious workforce, overall it looks more impressive than parallel efforts in other countries in Europe (Gumbrell-McCormick and Hyman, 2013). Table 2 illustrates the membership of the Italian union federations of atypical workers which has been constantly increasing in the last years, although the absolute number of members is still quite low in relative terms.

[Table 2 about here]

The new federations show clear differences as far as their general strategy towards atypical work is concerned. For example, FeLSA and UILTem.p@ are more inclined to embrace an individual 'servicing' model to target atypical workers with different contractual situations and needs. By contrast, NIDIL continues to give importance to a labour law reform which would restrict the number of contractual options available to companies and is directly opposed to the use of certain contracts, such as staff-leasing. Political bargaining is also a strategy directed at filling the gap in the economic convenience for atypical contracts in comparison to typical ones, by increasing the contributions required to use the former and avoid 'contractual dumping' by companies. An example of these differences is the attitude towards those bogus autonomous workers who in fact depend on a single company and are not covered by collective agreements. Italian atypical union federations tend to work on a decentralised level to regularise these situations, both through collective bargaining and by reporting illegal cases.

The specific new federations represent atypical workers in the political arena through national and company level bargaining, political and legal action, campaigning and collective mobilisation in order to search for an unification of the labour and social conditions (including wages) between typical and atypical workers as well as to set up agreements (particularly within companies) to transform non-standard contracts to standard ones (Ballarino, 2005). For example, in 2009 the Youth policies department of CGIL ${ }^{\mathrm{i}}$ in coordination with NIDIL-CGIL launched a campaign on 'Giovani non piu' disposti a tutto' ('Young people not anymore ready for everything"). As the president of the Youth department of CGIL states: 
"The campaign aimed at underlining that young people should not accept the current humiliating conditions to access the labour market, and the precarious jobs that are offered to them, and which do not allow them to build their own present and future" (Brussels, October 2014).

The campaign was addressed not only to CGIL itself but to union representatives and delegates at all levels in order to increase awareness inside the confederation, but also to the general public. This is why several actions followed the launch of the campaign, which dominated the media, virtual networks and blogs overall. We mention here the 'National Gathering Santa Impazienza' in Tuscany - July 2010 followed by the National demonstration in Rome on 27 November 2010, and thereafter in April 2011 the national demonstration and the foundation of the committee called 'Our time is now. Life won't wait'. ii

Federations for atypical workers obviously develop their work inside their respective trade union confederations. This may raise concerns as regards the possibility that these structures become forms of segregation, and thereby further marginalisation, for those workers inside the union (Murgia and Selmi in Hyman, 2015). Yet as the president of CGIL-NIDIL explained to us in an interview, the existence of federations for atypical workers allows the unions to coordinate their action with other federations, and thereby to promote a more general and encompassing agenda that gives space to the needs of atypical workers. On the other side, although NIDIL follows the main political guidelines of the confederation to which it belongs to, it maintains its contractual autonomy, which potentially strengthens the capacity of the federation to protect atypical workers through collective negotiation. In this respect, the president of CGIL-NIDIL in an interview (Brussels, October 2014) reported that in November 2014 already fifteen company-level agreements were negotiated by the NIDIL-CGIL under the so-called contrattazione aziendale inclusiva (inclusive company-level bargaining). The aim is to overcome workforce segmentation and marginalisation of the atypical workers through extending bargaining coverage and fostering transitions from atypical towards typical contracts.

In addition, the atypical workers union federations have offered various services to atypical workers, particularly with respect to the dissemination of information on social protections, rights, legal framework etc. For example, in 2009 NIDIL-CGIL, together with the youth department of CGIL, proceeded to integrate the function of social protection and improvement of the working conditions of the NIDIL with the activity of delivering services and consultancy for precarious people. As a result, in 2008 a Sportello Orientamento al Lavoro Unificato NIDIL (an office for the job orientation of precarious young people or Sportello Unificato NIDIL-SOL) was created within the CGIL Camera per il Lavoro in Milan to strengthen the organisational ties of the unions with the territory while helping precarious workers searching for 'good quality jobs'. Unions intend to use these structures as a means to increasing awareness of the 'legal' national labour market framework among the precarious workers. Trade unions thus act as provider of education and learning activities to young workers.

The creation of federations of atypical workers in Italy has not been a painless process. For a long time, some sectoral federations felt threatened by the functioning and the existence of these new structures (Leonardi, 2010). In the case of CISL, Alai was not a federation until 2009 when the delegates acquired voting rights. Even now, all atypical federations denounce the resistance of other sectoral federations to let their delegates approach workers or bargain with employers. The fundamental conflict is representation. As a representative from Alai reports, sectoral federations in Italy consider that there is no basic conflict of interest between typical and atypical workers and that the representation and defence of atypical workers should naturally be their task:

"Workers in the same workplace share all the same issues and interests" (Rome, February, 2011)

In the case of CGIL another reason is that sectoral unions are against the fragmentation of the representation of workers and oppose representation on an individual basis. Federations 
of atypical workers, by contrast, consider that sectoral unions can often be interested in keeping atypical workers in a precarious condition to better protect workers on standard contracts. The dialogue between federations seems, however, to have improved in recent years. Industrial federations have acknowledged the important role and the success in affiliation played by atypical federations, while they appear themselves more inclined to include precarious workers' issues on their agendas.

Specific strategies vary according to the workers' contractual status and tend to adopt a 'top-down' approach in order to deal with the recruitment of atypical workers. As mentioned above, atypical federations signed a multiemployer collective agreement with the federation of work agencies (Assolavoro) to cover agency workers. This strategy was possible because of the existence of an employer organisation comprising all temporary agencies and functioning as a bargaining counterpart. This contract makes the use of agency work quite expensive for companies but also ensure some flexibility for its use.

Resources for vocational training, health and safety, and other welfare provisions are also jointly managed by Italian unions and the employers' organisation through the use of 'bilateral' structures which receive a generally positive evaluation by union officers. Another example is the collective agreement covering the so-called 'Tagesmutter' (day-care mothers) signed by FeLSA and UIL Tem.p@ and the employer organisation 'AssociazioneDomus'. These strategies are adapted to the different sectors insofar as different sectors have different types of atypical workers.

The measures taken by the Italian union federations of atypical workers to target precarious workers depend also on the relations with sectoral organisations and are intertwined with their specific strategies. There are cases where these strategies collide. The public sector is a clear example of this, since the increasing use of atypical workers threatens the condition of permanent workers. Public sector unions place a strong emphasis on political pressure in order to limit the use of atypical workers, while atypical unions try to mobilise them in order to improve their working conditions.

\section{Unions and precarious work: Spain}

Spanish unions have not reacted to the upsurge of temporary employment by setting up specific federations for the representation of temporary workers. As has happened with other challenges faced throughout the 1980s and 1990s, Spanish trade unionism showed a preference for dealing with temporary employment at the top level, rather at the rank-and-file one; that is, to deal with it politically, rather than organisationally. In spite of the low membership rate, Spanish trade unions have always relied on institutions that reinforce their role, not so much at the bottom, but at higher levels in the national system of industrial relations (Ortiz, 1999).

At a broad political level, both UGT and CCOO initially gave way to the introduction of a deregulation of temporary employment 'at the margin' of the labour market. But important distinctions in this respect should be made between these two trade union confederations. Thus, while UGT supported the deregulation at the margins introduced by the Spanish Socialist Party (PSOE), CCOO strongly opposed it, arguing that it harmed the level of employment security Spanish workers had enjoyed so far. One of our interviewees, a former general secretary of $\mathrm{CCOO}$, reminded that the first step in the deregulation of the Spanish labour market (the labour market reform issued in 1984) came after an agreement between PSOE and UGT that was rejected by CCOO. And a general strike called by CCOO not long after, in 1985, did not meet with the support of UGT.

In spite of its initial reluctance, such partial deregulation of the labour market was later assessed by $\mathrm{CCOO}$ as a minor loss, relative to a deregulation of permanent work (Fernandez Macias, 2003). Permanent workers were the core of trade union membership, and Spanish trade unions reacted accordingly. As a result, youth was to bear the brunt of the employment precariousness that massively increased in the Spanish labour market the years to come. This might be the reason why 'Juventud sin Futuro' (Youth without Future), a movement aimed at denouncing the precariousness of youth employment that was born around the Spanish 
Indignados or 15-M social mobilisation of May $15^{\text {th }} 2011$, explicitly dissociated itself from any political party or, what is even more worrying, from any major trade union confederation: "they do not represent us" was one of their mottos, referring precisely to traditional political parties and unions alike (Flesher Fominaya, 2014, 2015; Hyman, 2015).

Yet, CCOO and UGT priority towards union members did not mean that they gave up any attempt at combatting temporary employment. On the contrary, according to Cerviño (2003), throughout the 1990s they were increasingly concerned with the alarming levels that temporary employment was reaching. For obvious reasons (saliently, job rotation) temporary workers were less prone to become union members. In the long run, temporary employment could lead to an increasing aging of union membership, a detachment from the Spanish working class, and a loss of legitimacy among the public opinion as a whole. Hence, if only at a political level, Spanish trade unions put the fight 'for stable employment' (por un empleo estable) at the forefront. The political struggle reached the point of calling a general strike in 1988 in response to the Youth Employment Plan (Plan de Empleo Juvenil), devised by PSOE to facilitate temporary employment to an even greater extent than the 1984 reform had made. Spanish trade unions also fiercely opposed the introduction of private employment agencies (ETTs, Empresas de Trabajo Temporal), that served to generate another type of atypical employment (Cerviño, 2003).

The reduction of the gap in dismissal costs between temporary and permanent workers enforced in 1997 can be seen as an additional sign of the compromise of Spanish trade unions with temporary workers, but here the position of CCOO and UGT was different again. In an interview the former general secretary of $\mathrm{CCOO}$ considered that such a concession came from $\mathrm{CCOO}$, and proved that $\mathrm{CCOO}$ was a trade union more committed to eliminating the inequality or distance between permanent and temporary work in Spain than UGT (Madrid, December 2014)

The increase of temporary employment in the public sector from 1997 onwards, though, reveals that such a measure was not enough to remove the strong segmentation of the Spanish labour market. Although trade unions denounced the abusive resort to temporary employment by employers and the state, insiders' job security was largely preserved and the flexibility of companies to deal with changes in product market demand was systematically attained by resorting to temporary employment. The fight against temporary employment never crossed the line of making temporary and permanent workers' employment conditions converge. Recent labour markets reforms in Spain have reduced the difference in protection between permanent and temporary contracts and were strongly opposed by the unions, which tried to defend the rights associated with open-ended contracts (Sanz de Miguel, 2011a).

An organisational response to temporary employment such as the one we have seen for Italy was in Spain more the exception than the rule. Yet, there were two organisational developments inside Spanish trade union confederations which resemble the role played by atypical workers' federations in Italy: youth associations and, more importantly, specific organisations for the representation of self-employed workers. As regards youth associations, Catalonia has been pioneer in their development inside Spanish trade unionism: AVALOT (UGT-Catalonia) and Acció Jove (CCOO) have been only recently set up. All union members of UGT and CCOO below 30 years of age in Catalonia automatically belong to AVALOT and Acció Jove, respectively. The general aim of these associations is to give young union members advice about different issues affecting them because of their age (housing, maternity leaves etc.). The higher incidence of temporary employment among young affiliates was not a particular goal mentioned. On the contrary, when informed about the reality in Italy, one of the members of Acció Jove explicitly rejected the idea of having specific federations for atypical workers:

"It makes no sense to set up a specific organisation for that purpose. Temporary workers should not be represented according to the nature of their contract, but according to work they carry out" (Barcelona, May, 2011) 
A sign of the lower internal importance of AVALOT and Acció Jove is the fact that they are associations, not federations, as in the Italian case. Both youth associations resemble youth associations in political parties, aimed at training cadres that later will be leading those federations: "The association was set up with the aim of becoming a school of cadres for the union" (Barcelona, May, 2011)

There are signs that the youth associations in Spain could play an incipient role in specifically representing atypical workers' interests inside the structure of the union. According to some CCOO trade union officials interviewed, the youth association indeed played a role in defending atypical workers interests', in the very same way as a secretariat for immigrants' workers did. Second, the interviewees in both associations mentioned the reluctance of the most powerful federations inside the union to accept the creation of AVALOT and Acció Jove. In the case of AVALOT, the general secretary of UGT-Catalonia had to overcome the resistance of some federations, like the Metalworking Federation. Moreover, in spite of a general discourse of harmony between youth associations and federations, there seemed to be situations when there was a potential conflict of interests between these youth associations and the traditional federations, as in the arrangement of lists for trade union elections at the workplace: if members of the youth associations were included there, there would be less room for accommodating older members. The case of IBERIA was also quite revealing of a potential conflict of interest between temporary and permanent workers. In one of the IBERIA workplaces, luggage porters, overwhelmingly hired on a temporary basis, had been suggested by the older union members to take their claims to AVALOT (UGT):

"Go to AVALOT; here we will deal with all the important issues at the workplace. These workers soon realised they were not being properly represented by the trade union branch". (Barcelona, May 2011)

Led by AVALOT, the workers mentioned in the quote above managed to call an assembly at that workplace and forced a change in the branch executive committee.

In spite of all this preliminary evidence of youth associations eventually becoming the embryo of future organisational units specifically aimed at representing atypical workers' interests, it must be acknowledged that they were nothing equivalent to the atypical workers' federations in Italy. They only defended the atypical workers' interests in a subsidiary way; they had not been set up to defend young workers because of the higher precariousness associated to youth in Spain.

A phenomenon much closer to the nature of atypical workers' federations in Italy is constituted by the specific organisations for the representation of self-employed workers set up inside CCOO and UGT. They should be regarded as a closer phenomenon to the atypical workers' federations in Italy because they were aimed at representing workers on the basis of their working status, and not of the basis of any ascriptive feature (age, gender or ethnicity). $\mathrm{CCOO}$ was clearly more advanced in this respect than UGT, and again Catalonia was pioneer in the development of such an internal organisation within CCOO. The name of the organisation in CCOO is TRADE. It represents self-employed workers whose activity is mostly aimed at providing services (at least 75\%) to a single customer. Such a relationship can be legitimately regarded as bogus self-employment and therefore as one of the types of atypical work considered in this article.

First established in Catalonia (interview with general secretary of TRADE for Spain), the General Congress of CCOO in 2008 decided to upgrade such a representation to the level of the whole confederation, and to stimulate similar changes in the other regional federations. But TRADE itself never became a federation; it was just a secretariat (lower level). With budget restrictions imposed by the Great Recession, it has even been downgraded to a department within the Secretariat of Social Protection and Public Policies. In sum, although more similar to the Italian atypical workers' federations than the youth association we have mentioned before, TRADE never attained the organisational importance that atypical workers' federations attained within Italian trade union confederations. 
In its inception, during 2008, there were certainly three positions as regards the status the representation of "dependent self-employed workers" (bogus self-employment) should attain inside CCOO: there was a minority who advocated that such a representation attain the status of a federation; an opposite position (also a minority) denied or rejected any possibility of any specific representation for these workers; finally, an intermediate one was the one that finally prevailed.

Some of the interviewees were aware that Italian trade union confederations had conferred a much more important representation to these interests within their respective organisations. In spite of this fact (and in spite of being aware of the possibility that atypical workers' interests were relegated during normal collective bargaining at the workplace level), they were critical of the strategy followed by Italian trade union confederations.

The account of the organisational response to atypical work by Spanish trade unions made so far immediately raises two questions: why Catalonia was a pioneer in these organisational developments; and why self-employed workers were able to attain a specific organisational representation inside the confederation that other atypical workers did not attain. As regards the latter question, one of the leading union officials of TRADE at state level revealed that half of its membership was constituted by former standard employees who had become self-employed as a result of the outsourcing of the services they currently provided to the companies they had formerly belonged to. Before becoming self-employed workers, they had been employees and union members of large companies. The other large group within TRADE was constituted by employees who had fallen into unemployment and had been almost forced to become self-employed due to the lack of jobs available. This association between selfemployment and precarious employment has already been well established for the Spanish case (Carrasco, 1999). Unlike other atypical workers, these self-employed workers could have been highly unionised before being forced into self-employment. Establishing TRADE was a way of preventing disconnection from the union of workers who had been union members before becoming self-employed. Finally, many interviews revealed a high concentration of 'dependent self-employment' in a number of occupations. Lorry and van drivers were systematically referred to as the paradigm of the member of TRADE. Such an occupational concentration (or lack of dispersion across sectors and occupations) may have also favoured a higher degree of organisational representation inside CCOO.

As regards the pioneering character of Catalonia in the establishment of some these organisational forms, several explanations were provided by the interviewees. Catalonia has traditionally been one of the leading industrial territories in Spain and, thus, one of the main strongholds of its labour movement: "having in mind that many dependent self-employed workers have industrial companies as their 'customers', it is not strange that TRADE was first established in Catalonia' (former general secretary of CCOO). This interview also vaguely mentioned the more "mature" (modern) character of trade unionism in Catalonia, vis-a-vis other regional federations.

\section{Explaining Italian and Spanish union response to precarious workers}

Although some traditional literature considers unions as protecting the interests of insiders versus outsiders (Lindbeck and Snower, 1986), our findings illustrate that in none of the two cases unions developed strategies of exclusion of atypical workers. However, our findings do show diversity in the unions' responses. This diversity depends on the specific national labour market, social welfare as well as industrial relations contexts and traditions, which confronted unions with different contextual situations as well as provided to them diverse resources that they could draw upon, within each national setting, to respond to precarious work.

One of the biggest problems for precarious employment in Italy is the absence of a complete and coherent reform of social security provision able to cushion the social effects of labour market deregulation. Although trilateral social negotiations during the 1990s aimed at increasing the financial sustainability of the Italian pension system in the long run (Colombo and Regini, 2009), they overlooked another important pillar of the welfare system, that is the 
social security provision concerning unemployment protection for atypical workers as well as measures to support social rights (e.g. sick leave, maternity) of non-standard workers. Italian unions used their strong bargaining position at sector and company level, derived from their higher membership in comparison with Spain, as well as their horizontal and vertical organisational logic, to create structures for the representation of atypical workers in the political and social arena through national and company level bargaining. Moreover, because of their strong bargaining activity in workplaces and sectors, they also used political action and campaigning to defend the interests of atypical workers. Although the Spanish unions gave the same importance as Italian unions to activities aimed at reducing precarious work, contrary to what happened in Italy, their discourses have been to some extent circumscribed to the national (State) level as the actual organisational and collaborative resources at the workplace are rather scarce. This is because of the comparatively weaker bargaining position of the Spanish unions at local and sector level. Spanish unions were thus more inclined to influence government policy and legislative reforms at the national level. The resources Spanish unions can draw from union elections at the national or regional level undoubtedly shaped their strategic approach to precarious work.

In Spain, the centrality of organising has been relatively lower than in Italy, which nevertheless seems to share with Spain the focus on the revival of tripartite agreements in the political sphere. The strategies of the Spanish unions have been influenced by the incentives established by the system of workers' representation at workplaces (Malo, 2006). Workers' representation was established in Spain at the 1980 Workers' Statute (Estatuto de los Trabajadores) and the 1985 Union Rights Act (LOLS, Ley Orgánica de Libertad Sindical). The 1985 LOLS created the status of 'most representative union', to be attained by trade unions that obtained at least $10 \%$ of workers representatives in union elections at the state level (or $15 \%$ at the regional one). The status of 'most representative union' entitles unions to participate in collective bargaining at sector, regional or state level and sign collective agreements that, due to erga omnes extension clauses, are applicable as law to all workers in a given domain, regardless of their union membership (Martinez Lucio, 1998).

In addition, state financial support also comes partly as a result of the number of representatives obtained at the union elections (Milner and Nombela, 1995). Although Spanish union finances are obscure, Escobar (1993) estimated for UGT that $41 \%$ of the annual income for the period from 1986-1989 came from state subsidies. In relative terms, Spanish trade unions thus become highly interested in trade union elections, and not so much interested in recruiting new members insofar as these members do not have the capacity to express their vote. As Malo shows (2006), temporary workers have a lower propensity to participate in union elections in Spain because they are more likely to be unemployed at the moment of the election or to move to a different company and sector. Therefore, they are less influential in the longterm results of their vote. As a result of all that, macro-level political pressure and nation-wide campaigns may turn into valid strategies for defending precarious workers' interests within the Spanish context.

Although the two main trade union confederations in Spain have cooperated in the 1990s to counteract declining membership (Heery and Adler, 2004) by adopting a policy of expansion towards women, young workers and the large proportion of employees engaged on temporary contracts, initiatives of this kind tended to remain rather symbolic as actual resources dedicated by the unions are often meagre (Keune, 2013). On the other hand these activities were mostly coordinated centrally by the confederation, and the linkage with the workplace remained rather weak.

Conversely, besides their traditional activities of collective bargaining at industry-wide and company levels, political initiatives vis-à-vis governments, and the provision of benefit advice and assistance to members and workers in general, Italian unions developed a wide range of further actions which extends into other levels and in other directions. Notable are the inclusive company-level agreements (contrattazione aziendale inclusiva) concluded by the unions with employers for the protection of employment, but also services offered to precarious workers (as the NIDIL-SOL) and social and welfare schemes for the local population as well as campaigning for political action. Besides the traditional distributive and productive functions of 
the Italian unions, therefore, one may now also speak of them as the largest and most ubiquitous organizations in civil society (Regalia, 2012). They are present with structures, both general and specific (i.e. the new federations for atypical workers), at all levels. They operate according to different logics and in numerous arenas, and their organizational strength and influence in this respect are equally as great as their memberships.

In addition, Italian unions have historically relied on membership mobilisation as the basic source of their power. Thereby, it may be argued that the fall in union membership, particularly during the years $90 \mathrm{~s}$ till mid-2000s, pushed Italian unions to elaborate strategies aimed not only at macro-level labour market and welfare reforms, but also at the affiliation, defence at the workplace, and mobilisation of precarious workers (see also Hyman, 2015).

Pointing out that the strategies followed by trade union confederations in Italy and Spain for representing atypical workers' interests reveal a clear national pattern, is enough to explain why the strategies followed by CGIL and CSIL, on the one hand, are closer to each other than the strategies followed by UGT or CCOO, on the other hand. But important nuances or differences need to be remarked, at least in the Spanish case. The difference between UGT and CCOO both at the political level (CCOO's stance towards partial deregulation, when it was first introduced, and to precarious employment during the negotiation of the 1997 labour market reform) and at the organisational level (higher salience or importance of organisational developments as TRADE) should possibly call our attention to the role of ideology in explaining different strategies for the representation of atypical workers' interests.

\section{Conclusion}

Italian and Spanish unions have given different responses to a common challenge they both faced in terms of rising precarious employment. Trade unions in Spain and Italy are embedded within distinctive institutional settings where the precarious work originated, and where unions could rely on specific resources in shaping their own responses.

Within a labour market and welfare context characterised by weak unemployment coverage to atypical workers, Italian unions have used their strong bargaining position at sector and company level, derived from their higher membership in comparison with Spain, as well as their horizontal and vertical organisational logic, to set up specific federations for the affiliation and representation of atypical workers. It was a way to improve health and safety practices, promote forms of stabilisation and deliver additional benefits and welfare measures for precarious, particularly atypical workers, who were excluded by those measures. Besides, Italian unions have also been active in organising campaigns against the abuse of certain atypical contract types. By contrast, by experiencing relatively weaker organisational and collaborative resources at the workplace level, in Spain trade unions have not set up specific federations for atypical workers. Youth associations have indeed played a role in defending atypical workers' interests, but they were not explicitly created for this purpose. The units set up to represent bogus self-employment are closer to the role played by Italian federations of atypical workers; yet, they do not have the organisational status Italian federations of atypical workers have insider their own organisations.

The different responses between the two countries reflect the reliance of Italian unions on micro-level membership compared to the stronger emphasis put by Spanish unions on macro-level political dialogue and pressure. For Italian unions, atypical workers may represent a way to keep up levels of affiliation and of power at the micro level. Large Spanish unions can instead be satisfied with their status of 'most representative union', achieved by obtaining a $10 \%$ national average turnout at union elections, to maintain their influence and gain legitimacy to engage in processes of macro level tripartite social dialogue. Further research on the differences in strategies across sectors, the internal process of structural changes (or attempts of) for the representation of atypical workers, and on experiences in other countries, would help further verify this argument.

In spite of clear national patterns in the unions' response to atypical work, there are subtle differences within the Spanish case that allow us to suspect that ideological reasons also 
played a role in distinguishing the reaction of $\mathrm{CCOO}$ from the reaction of UGT. The reaction or strategy of the former was closer to the unions' reaction seen in Italy and closer therefore to an organising model. Even if constrained by the same institutional environment, the two main trade union confederations in Spain showed minor but meaningful and relevant differences

${ }^{\text {i } I n} 2009$ a Youth Policies Department of CGIL was created at national level to raise awareness about youth policies at both national and regional level, including all the different national workers federation.

ii It followed the 2004 San Precario movement, named by the "patron saint" of temporary workers (cfr. Hyman, 2015) 


\section{References}

Accornero A (2006) Il Mondo della produzione. Sociologia del lavoro e dell'industria, Bologna: Il Mulino.

Altieri G (2009) Un mercato del lavoro atipico. Roma: Ediesse

Baccaro L, Hamann K, and Turner L. (2003)'The Politics of Labor Movement Revitalization: The Need for a Revitalized Perspective. European Journal of Industrial Relations 9(1): 119133.

Bacon N and Blyton P (2004) Trade Union Responses to Workplace Restructuring: Exploring Union Orientations and Actions'. Work, Employment and Society 18(4): 749-773.

Ballarino G (2005) Strumenti nuovi per un lavoro vecchio. Il sindacato italiano e la rappresentanza dei lavoratori atipici. Sociologia del lavoro 97:174-190.

Barbieri P and Scherer S (2009) Labour Market Flexibilization and its Consequences in Italy. European Sociological Review 25(6): 677-692.

Barbieri P (2011) Italy: no country for young men (and women): the Italian way of coping with increasing demands for labour market flexibility and rising welfare problems. In Blossfeld HP, Buchholz S, Hofäcker D and Kolb K (eds) Globalized Labour Markets and Social Inequality in Europe. London: Palgrave Macmillan. Pp. 108-145

Berton F, Richiardi M and Sacchi S (2009) Flex-insecurity. Perché in Italia la flessibilità diventa precarietà. Bologna: Il Mulino.

Carré FJ, Ferber M, Golden L, and Herzenberg S (2000) Nonstandard work: the nature and challenges of changing employment arrangements. In Carré FJ, Ferber M, Golden L, and Herzenberg S (eds) Nonstandard Work, IRRA: University of Illinois. Pp 1-20

Cella GP (2012) The representation of non-standard workers: Theory and culture of collective bargaining. Transfer 18(2): 171-184.

Choi $\mathrm{H}$ and Mattoni A (2010) The Contentious field of precarious work in Italy: Political actors, Strategies and coalitions. The Journal of Labor and Society, 13: 213-243.

Boxall P (2009) Trade Union Strategy. In Dolyton PB, Heery E, Bacon N and Fiorito J (eds) The SAGE Handbook of Industrial Relations. Thousand Oaks, California: SAGE Publications. pp.209-224

Burroni L and Carrieri M (2013) Bargaining for social rights (Barsori). Country report: Italy. University of Teramo, unpublished

Cerviño E (2003) Políticas de representación sindical: UGT y CCOO ante el empleo temporal. Madrid: Centro de Estudios Avanzados en Ciencias Sociales.

CGIA Mestre (2012) Precari: ecco l'identikit redatto dalla Cgia. Available at: http://www.cgiamestre.com/2012/05/precari-ecoo-lidentikit-redatto-dalla-cgia/ (accessed 30 October 2012). 
Conde-Ruiz JI, Felgueroso F and García Pérez JI (2010) Las reformas laborales en España: un modelo agotado. Papeles de Economía 124: 128-146.

Dolado JJ, García-Serrano C, and Jimeno JF (2002) Drawing Lessons from the Boom of Temporary Jobs in Spain. The Economic Journal 112(480): 270-295

Escobar M (1993) Works or Union Councils? The Representative System in Medium and Large Sized Spanish Firms. Instituto Juan March de Estudios e Investigaciones, Working Paper No.43.

Evans J and Gibb E (2009) Moving from Precarious Employment to Decent Work. GURN discussion paper no.13. Geneva: International Labour Office, Global Union Research Network (GURN).

Falguera i Baró MA (1991) La legislación individual de trabajo. In Míguelez F and Prieto C (eds) Las relaciones laborales en España. Madrid: Siglo XXI. pp.271-287.

Fernández Macías E (2003) Job Instability and Political Attitudes Towards Work: Some Lessons from the Spanish Case. European Journal of Industrial Relations 9(2): 205-222.

Fiorito J and Jarley P (2009) Trade Union Morphology. In Blyton P, Heery E, Bacon N and Fiorito J (eds). The SAGE Handbook of Industrial Relations. Thousand Oaks, California: SAGE Publications. pp. 189-208.

Flesher Fominaya, Cristina (2014) Social Movements \& Globalization. How Protests, Occupations \& Uprisings are Changing the World. New York: Palgrave Macmillan.

Flesher Fominaya, Cristina (2015) 'Debunking Spontaneity: Spain's 15-M/Indignados as Autonomous Movements', Social Movements Studies 14(2): 1-22

García Polavieja J. (2005) Flexibility or polarization? Temporary employment and job tasks in Spain. Socio-Economic Review 3: 233-258.

Gumbrell-McCombrick R (2010) European trade unions and 'atypical' workers. Industrial Relations Journal 42(3): 293-310.

Gumbrell-McCombrick R and Hyman R (2013) Trade unions in Western Europe, Oxford: Oxford University Press

Heery E (2009) Trade Unions and Contingent Labour: Scale and Method. Cambridge Journal of Regions, Economy and Society 2: 429-442.

Heery E and Adler L (2004) Organizing the Unorganized. In Frege C and Kelly J (eds.) Varieties of Unionism. Oxford: Oxford University Press. pp.45-70.

Hipp L, Bernhardt J and Allmendinger J (2015) Institutions and the prevalence of non-standard employment . Socio Economic Review, doi: 10.1093/ser/mwv002

Hyman R (2015) Austeritarianism in Europe: What Options for Resistance?', Paper for the Institute for New Economic Thinking conference 'Liberté, egalité, fragilité', Paris, April https://www.dropbox.com/sh/cyy9mpgq76gidr5/AADfryx Bnczj0kWcPetacha/2_Friday\%204.10.2015/Occupy\%20Strike\%20Separatism\%20Populism/HYMAN\%2 0-\%20AUSTERITARIANISM\%20IN\%20EUROPE.pdf?dl=0

IRES (2010) Dal lavoro interinale alla somministrazione. Roma: Ebitemp. 
Kay S., Jefferys S., Paraksevopoulou A., Keles J. (2012) Study on Precarious work and social rights, European Commission: Brussels

Keune M (2013) Trade union responses to precarious work in seven European countries. BARSORI project.

Kretsos, L (2011) Union responses to the rise of precarious youth employment in Greece. Industrial Relations Journal 42(5): 453-472.

Leonardi S (2010) Union organisation of employees in atypical and precarious work in Italy. In Garibaldo F and Telljohann V (eds.) The Ambivalent Character of Participation. Frankfurt am Main: Peter Lang.

Leonardi S (2009) The future of the welfare state: paths of social policy innovation between constraints and opportunities, paper presented at the $7^{\text {th }}$ ESPAnet Conference, Urbino.

Lodemel I and Trickey H (2001) An Offer You Can't Refuse: Workfare in International Perspective. Bristol: Policy Press.

Mailand M and Larsen TP (2011) Trade unions and precarious work - Danish country report to the BARSORI-project. Copenhagen: FaOS.

Malo MA (2006) Temporary Workers and Direct Voting Systems for Workers' Representation. Economic and Industrial Democracy 27(3): 505-535.

Molina O (2007) State and Regulation of Industrial Relations in Spain: Old Wine in a New Governance Bottle?. South European Society and Politics 12(4): 461-479.

Ortiz L (1999) Unions' Response to Teamwork: Differences at National and Workplace Level. European Journal of Industrial Relations 5(1): 49-69.

Regalia I (2012) Italian Trade Unions: Still Shifting between Consolidated Organizations and Social Movements?. Management Revue 23(4), 386-407.

Rymkevich O (2013) Labour law reforms in Italy and the problema of precarious employment, Paper presented at the Labour Law Research Network Inaugural Conference: Barcellona.

Terry M (1993) Workplace Unions and Workplace IR: The Italian Experience. Industrial Relations Journal 24(2): 138-150.

Vandaele K and Leschke J (2010) Following the "Organising Model" of British Unions? Organising Non-Standard Workers in Germany and the Netherlands. ETUI Working Paper 2010/02. Brussels: ETUI. 
Table 1: Labour markets and industrial relations indicators

\begin{tabular}{|c|c|c|c|c|c|c|c|c|c|c|c|c|c|}
\hline & \multicolumn{3}{|c|}{ Employment rate } & \multicolumn{3}{|c|}{$\begin{array}{l}\text { Fixed-term } \\
\text { contracts }\end{array}$} & \multicolumn{3}{|c|}{$\begin{array}{l}\text { Temporary } \\
\text { contracts }(15-29)\end{array}$} & \multicolumn{3}{|c|}{$\begin{array}{l}\text { EPL } \\
\text { Regular } \\
\text { Non- regular }\end{array}$} & \multirow[t]{2}{*}{$\begin{array}{l}\text { Union } \\
\text { density per } \\
\text { age group } \\
(2010-2012)\end{array}$} \\
\hline & 2002 & 2008 & 2011 & 2002 & 2008 & 2011 & 2002 & 2008 & 2011 & 2002 & 2008 & 2011 & \\
\hline EU-27 & 62,4 & 65,8 & 64,3 & 12.4 & 14.2 & 14.2 & 28 & 29,7 & 31.3 & & & & \\
\hline Spain & 58.5 & 64.3 & 57,7 & 32,1 & 29,4 & 25,6 & 51 & 46,4 & 47,1 & $\begin{array}{l}2.3 \\
3.2\end{array}$ & $\begin{array}{l}2.3 \\
3\end{array}$ & $\begin{array}{l}2.2 \\
2.5\end{array}$ & $\begin{array}{l}\text { 18-24: } 1.77 \% \\
\text { 25-49: } 2.57 \% \\
50-65: 2.89 \%\end{array}$ \\
\hline Italy & 55,5 & 58,7 & 56,9 & 9,9 & 13,9 & 13,7 & .. & 36,5 & 36,6 & $\begin{array}{l}2.7 \\
2.3\end{array}$ & $\begin{array}{l}2.7 \\
2\end{array}$ & $\begin{array}{l}2.7 \\
2\end{array}$ & $\begin{array}{l}\text { 18-24: } 2 \% \\
\text { 25-49: } 7.10 \% \\
50-65: 8.44 \%\end{array}$ \\
\hline
\end{tabular}

Source: Keune (2013) ; European Social Survey data and Eurostat

Note: Figures on union density by age for Spain are drawn from the $5^{\text {th }}$ round of the ESS (2010); for Italy, they have been drawn from the $6^{\text {th }}$ round of the ESS (2012)

Table 2: Affiliation in atypical federations in Italy

\begin{tabular}{|l|l|l|l|}
\hline Year & CGIL - NIDIL & CISL - FeLSA & $\begin{array}{l}\text { UIL } \\
\text { Tem.p@ }\end{array}$ \\
\hline 2003 & 16,762 & 21,530 & \\
\hline 2004 & 18,640 & 24,514 & \\
\hline 2005 & 22,320 & 26,375 & \\
\hline 2006 & 29,408 & 27,376 & \\
\hline 2007 & 32,799 & 27,698 & \\
\hline 2008 & 36,026 & 29,361 & \\
\hline 2009 & 41,628 & 28,233 & 20,100 \\
\hline 2010 & 53,304 & $47,653^{*}$ & 22,195 \\
\hline 2011 & 61,004 & 44,334 & $\ldots{ }^{* *}$ \\
\hline 2012 & 67,000 & $\ldots \ldots$ & $\ldots{ }^{* *}$ \\
\hline
\end{tabular}

Source: NIDIL-CGIL , CISL-FeISA and UIL Tem.p@

* Internal merger with another association

** UIL Tem.p@ does not publishes data regarding the number of affiliated (see also Ballarino,

2005). The data recuperated for 2009 and 2010 were disclosed during the interviews.

\section{Graph 1}




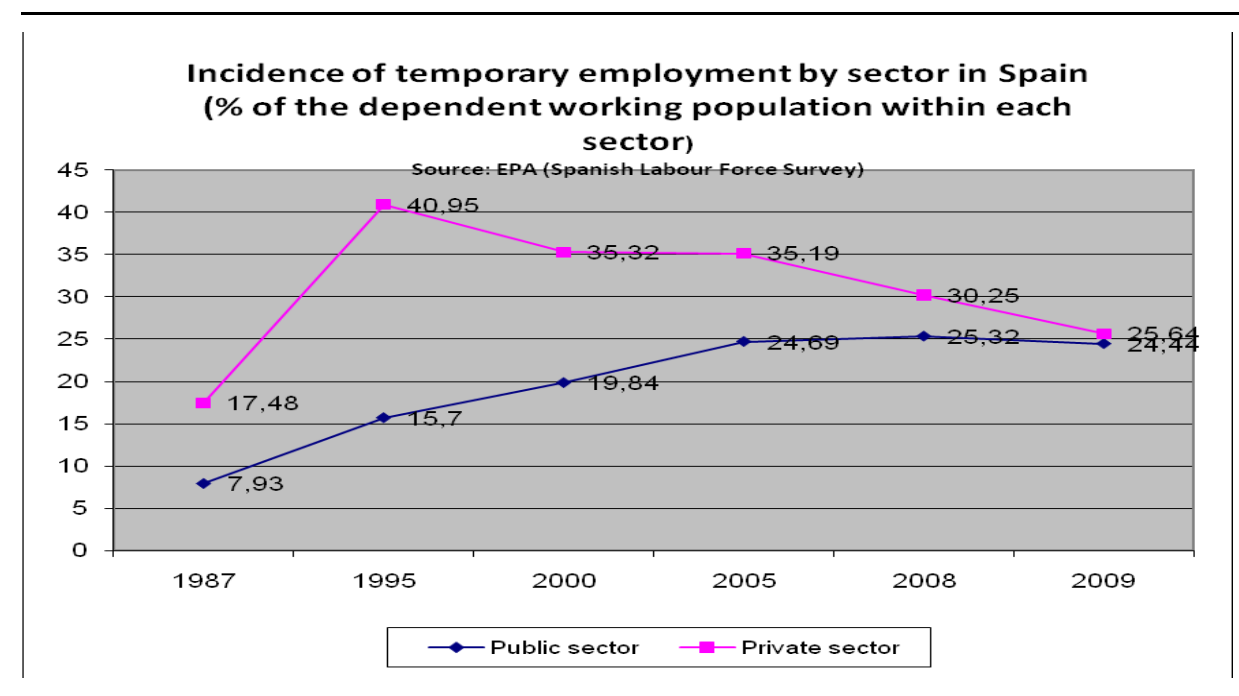

